Article

\title{
Performance of an Active Micro Direct Methanol Fuel Cell Using Reduced Catalyst Loading MEAs
}

\author{
D.S. Falcão ${ }^{1, *}$, R.A. Silva ${ }^{2}$, C.M. Rangel ${ }^{2}$ (1) and A.M.F.R. Pinto ${ }^{1, *}$ \\ 1 CEFT, Departamento de Engenharia Química, Faculdade de Engenharia da Universidade do Porto, \\ Rua Dr. Roberto Frias, s/n, 4200-465 Porto, Portugal \\ 2 LNEG, Laboratório Nacional de Energia e Geologia, Fuel Cells and Hydrogen, Paço do Lumiar, 22, \\ 1649-038 Lisboa, Portugal; raquel.silva@lneg.pt (R.A.S.); carmen.rangel@lneg.pt (C.M.R.) \\ * $\quad$ Correspondence: dfalcao@fe.up.pt (D.S.F.); apinto@fe.up.pt (A.M.F.R.P.); Tel.: +351-22-508-1675 (A.M.F.R.P.)
}

Received: 11 September 2017; Accepted: 21 October 2017; Published: 25 October 2017

\begin{abstract}
The micro direct methanol fuel cell (MicroDMFC) is an emergent technology due to its special interest for portable applications. This work presents the results of a set of experiments conducted at room temperature using an active metallic MicroDMFC with an active area of $2.25 \mathrm{~cm}^{2}$. The MicroDMFC uses available commercial materials with low platinum content in order to reduce the overall fuel cell cost. The main goal of this work is to provide useful information to easily design an active MicroDMFC with a good performance recurring to cheaper commercial Membrane Electrode Assemblies MEAs. A performance/cost analysis for each MEA tested is provided. The maximum power output obtained was $18.1 \mathrm{~mW} / \mathrm{cm}^{2}$ for a hot-pressed MEA with materials purchased from Quintech with very low catalyst loading $\left(3 \mathrm{mg} / \mathrm{cm}^{2} \mathrm{Pt}-\mathrm{Ru}\right.$ at anode side and $0.5 \mathrm{mg} / \mathrm{cm}^{2} \mathrm{PtB}$ at the cathode side) costing around 15 euros. Similar power values are reported in literature for the same type of micro fuel cells working at higher operating temperatures and substantially higher cathode catalyst loadings. Experimental studies using metallic active micro direct methanol fuel cells operating at room temperature are very scarce. The results presented in this work are, therefore, very useful for the scientific community.
\end{abstract}

Keywords: MicroDMFC; experimental studies; commercial MEAs; low catalyst loading

\section{Introduction}

The growing interest in electronic power generating devices and the great development of microelectromechanical systems (MEMS) technology make micro methanol fuel cells a strong candidate to substitute batteries [1]. To achieve high power densities with an attractive cost-to-power ratio, a liquid fuel such as methanol seems to be the best alternative. An important advantage of MicroDMFCs is room temperature operation leading to a reduction of heat management challenges for small systems.

The key component of the fuel cell is the membrane electrode assembly (MEA) that consists of the anode and cathode diffusion and catalytic layers and the membrane. Usually, the membranes for MicroDMFC are made of perfluorinated sulfonic acid membranes, which were developed by DuPont and sold under the commercial name of Nafion. Methanol crossover is one of the major problems regarding micro methanol fuel cells technology [2,3]. Some of the methanol does not react at the anode side and passes through the membrane to the cathode side leading to fuel cell performance losses. Another important issue is the control of the micro two-phase flows occurring at the anode and cathode of the micro fuel cell: the $\mathrm{CO}_{2}$ bubbles formed at the anode eventually blocking the flow and the formation and removal of water drops at the cathode. Gas diffusion layers (GDL), catalyst loading and Nafion thickness should be carefully chosen in order to minimize these problems. The most common used catalysts in DMFCs are Pt-Ru on the anode side and $\mathrm{Pt}$ on the cathode side, although 
the very high cost of these materials is a major obstacle to commercialization [4-6]. The diffusion layers do not participate directly in the electrochemical reactions but have important roles [6,7]: they enable reactants to access the catalyst active sites; allow the products' removal from the catalyst layer; electrically connect the catalyst layer to the flow field plate; allow heat removal; and provide mechanical support to the MEA. To achieve these goals, the diffusion layers are usually based on carbon fiber materials such as carbon papers and carbon cloths. Carbon cloth is more porous and less pliable than carbon paper, although carbon paper has excellent electronic conductivity. In order to avoid flooding, the cathode diffusion layers are generally hydrophobic since this facilitates the removal of excess water in the cathode catalyst layer from the cell. To fulfill these goals, typically, the gas diffusion layers are treated with PTFE (polytetrafluoroethylene). However, the anode diffusion layer of a DMFC should be hydrophilic to improve the mass transfer of the dilute methanol solution to the anode.

Nafion 117 membranes are used in a significant amount of studies [8-13]. The catalyst loading used on the anode side is typically $4 \mathrm{mg} / \mathrm{cm}^{2} \mathrm{Pt}-\mathrm{Ru}$. Considering the cathodic catalyst loading, the values are between 1.5 and $4.0 \mathrm{mg} / \mathrm{cm}^{2}$ Platinum Black PtB. The commonly used diffusion layers are made of carbon paper with different treatments for both fuel cell sides. There are few works analyzing the effect of anode and/or cathode catalyst loadings. For microDMFCs, Hashim et al. [14] tested Nafion 117 in a passive stack with different catalyst loadings $\left(2,3\right.$ and $\left.4 \mathrm{mg} / \mathrm{cm}^{2}\right)$ at the anode side. At the cathode side a $2.0 \mathrm{mg} / \mathrm{cm}^{2}$ constant catalyst loading was used. The authors concluded that better fuel cell stack performances $\left(12 \mathrm{~mW} / \mathrm{cm}^{2}\right)$ were obtained for a catalyst loading of $3.0 \mathrm{mg} / \mathrm{cm}^{2}$. Gogel et al. [15] tested, in a DMFC with $25 \mathrm{~cm}^{2}$ area, a Nafion 105 membrane operating at $110^{\circ} \mathrm{C}$ with cathode catalyst loadings between 1 and $6.3 \mathrm{mg} / \mathrm{cm}^{2} \mathrm{PtB}$ with an anode loading of $5.4 \mathrm{mg} / \mathrm{cm}^{2} \mathrm{Pt}-\mathrm{Ru}$. The authors concluded that the reduction of platinum loading in the cathode leads to a concurrent decrease in performance. The performance lowers gradually down to a cathode catalyst loading of about $2 \mathrm{mg} / \mathrm{cm}^{2}$. However, when the platinum content is reduced from 2 to $1 \mathrm{mg} / \mathrm{cm}^{2}$ the performance is notably diminished by about $300 \mathrm{mV}$ (corresponding to performances approximately four times lower).

Concerning the cell design, the materials used as carrier substrate are mainly silicon and stainless steel. Stainless steel enables higher fuel cell performances to be achieved, although there are relatively few studies using this substrate $[10,16-19]$ because of a higher machining cost. Experiments on active metallic micro fuel cells operating at room temperatures are very scarce [20,21]. Lu and Wang [20] tested a stainless steel active micro direct methanol fuel cell and obtained a maximum power density of $34 \mathrm{~mW} / \mathrm{cm}^{2}$ at $22{ }^{\circ} \mathrm{C}$ using a MEA with $4.8 \mathrm{mg} / \mathrm{cm}^{2} \mathrm{Pt}-\mathrm{Ru}$ at the anode side and $1.8 \mathrm{mg} / \mathrm{cm}^{2} \mathrm{Pt}$ at the cathode side. Zhang et al. [21] reached (also with a metallic active microDMFC) a power output of $32.87 \mathrm{~mW} / \mathrm{cm}^{2}$ at $20^{\circ} \mathrm{C}$ using a MEA with an anode catalyst loading of $4 \mathrm{mg} / \mathrm{cm}^{2} \mathrm{Pt}-\mathrm{Ru}$ and a cathode catalyst loading of $2 \mathrm{mg} / \mathrm{cm}^{2} \mathrm{PtB}$. Another relevant work operating at room temperature but using a silicon based MicroDMFC was presented by Lu and Reddy [22]. The best performance achieved using the single serpentine flow field design was $16.2 \mathrm{~mW} / \mathrm{cm}^{2}$ with a Nafion 112-based membrane with an anode catalyst loading of $5 \mathrm{mg} / \mathrm{cm}^{2} \mathrm{Pt}-\mathrm{Ru}$ and a cathode catalyst loading of $5 \mathrm{mg} / \mathrm{cm}^{2} \mathrm{Pt}$.

This research presents an experimental study using a metallic microDMFC with an active area of $2.25 \mathrm{~cm}^{2}$. A set of experiments using several commercially available MEAs was performed using different methanol concentrations at room temperature, a condition of special interest taking into account portable applications. A comparison between performances and prices of each MEA tested was also performed. The main innovation of the current work is the use of a very low platinum content at the cathode side $\left(0.5 \mathrm{mg} / \mathrm{cm}^{2}\right)$ and also considerably low platinum/ruthenium content at the anode side $\left(3 \mathrm{mg} / \mathrm{cm}^{2}\right)$.

\section{Experimental}

The cell comprises two acrylic end plates and two golden stainless steel current collectors with serpentine design (machined by MicroSystems, Warrington, UK). The single-serpentine flow field design is shown to be one of the most favorable for the micro DMFC [4]. The thickness of the stainless 
steel plate is $300 \mu \mathrm{m}$ and 20 channels. Width and length are respectively, $375 \mu \mathrm{m}$ and $1.5 \mathrm{~cm}$. A cell representation is given in Figure 1.

The experimental rig consists of a rotameter for air flow, a peristaltic pump (Control CO) for methanol flow and an electrochemical station (Zennium from Zahner ZAHNER-elektrik, Kronach, Germany) to obtain the polarization curves. Different methanol concentrations ranging from 1 to $4 \mathrm{M}$ were used to study the effect of methanol concentration on the cell performance.

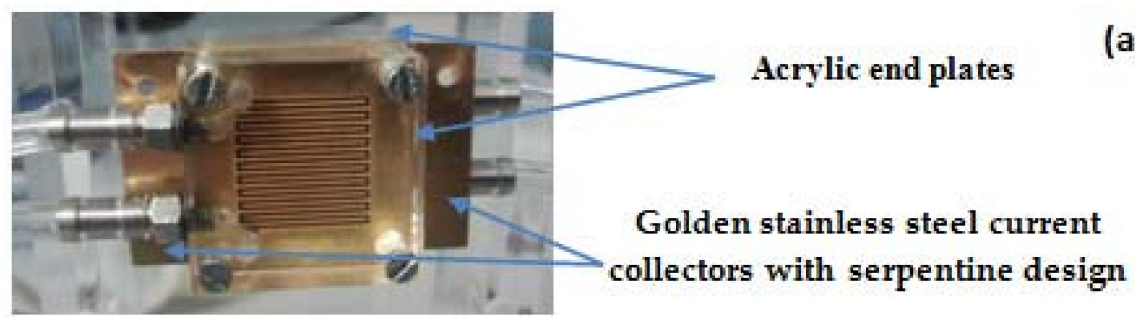

(a)

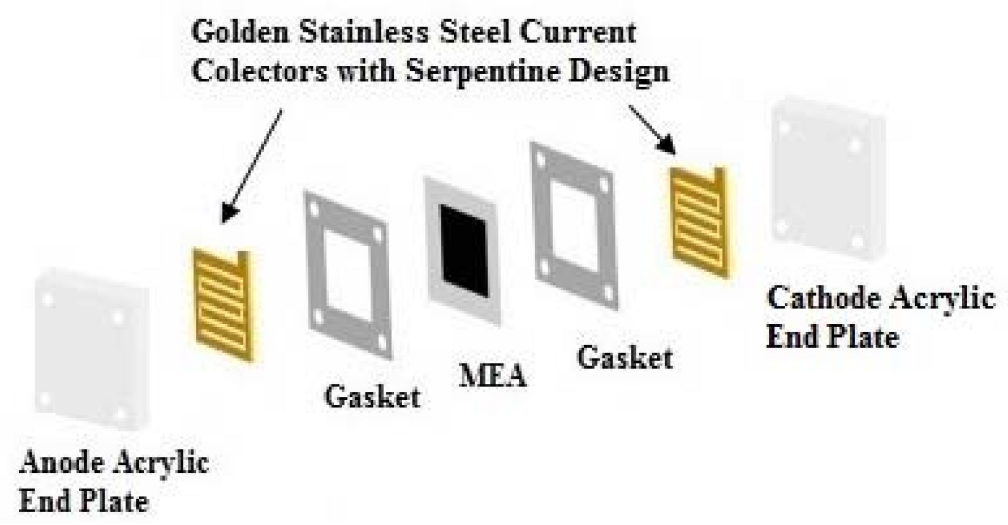

(b)

Figure 1. micro direct methanol fuel cell (MicroDMFC) (a) picture (b) drawing. MEA denotes membrane electrode assembly.

The main purpose of the present work was to design cheaper MEAs with commercially available materials, therefore the authors decided to purchase electrodes with a substantially lower catalyst loading of $0.5 \mathrm{mg} / \mathrm{cm}^{2} \mathrm{Pt}$. and a relatively low anode catalyst loading of $3 \mathrm{mg} / \mathrm{cm}^{2} \mathrm{Pt}-\mathrm{Ru}$. Optimised GDLs seem to be adequate for generating proper water management in the cathode and were tailored together with Nafion membranes as MEAs QN1 to QN4 (Table 1).

Nafion 117 and 115 were employed as polymer electrolyte membranes. Pre-treatment of the membranes for protonation and removal of organic and metallic impurities was carried out through the following steps, each with the duration of $1 \mathrm{~h}$. After boiling in distilled water (DW) the membranes were immersed in $3 \% \mathrm{H}_{2} \mathrm{O}_{2}$ at $80{ }^{\circ} \mathrm{C}$ followed by rinsing in DW at $80^{\circ} \mathrm{C}$. The protonation process took place in a $0.5 \mathrm{M} \mathrm{H}_{2} \mathrm{SO}_{4}$ solution at $80^{\circ} \mathrm{C}$. Afterwards, the membranes were again rinsed in distilled water $\left(80^{\circ} \mathrm{C}\right)$, which was done three times. The membranes were kept in water until MEA fabrication before which the excess water was removed.

In order to fabricate the MEA and attain a good interfacial contact between layers, a dry hot pressing procedure was used to assemble the anode and cathode layers. The active area is $2.25 \mathrm{~cm}^{2}$.

A bench top laboratory press with electrically heated platens by Carver, model 3856, was used. A hot pressing constant temperature of $130{ }^{\circ} \mathrm{C}$ was selected. Regarding pressing pressure and time, several attempts were made using values in the intervals of $70-35 \mathrm{kgf} \mathrm{cm}^{-2}$ and $3-5.5 \mathrm{~min}$, respectively. Within the studied interval the lower values of pressure and time, $35 \mathrm{kgf} \mathrm{cm}^{-2}$ and $3 \mathrm{~min}$, gave the best results in terms of adherence of the layers after cooling and compression ratios of the anode and cathode. 
The characteristics of the MEAs' components (including catalyst loading and GDL material) used in the in-house designed micro-direct methanol fuel cell are summarized in Table 1. Nafion and electrodes (gas diffusion layers with catalytic deposition) were purchased from Quintech.

Table 1. Characteristics of the MEA's used in this work.

\begin{tabular}{|c|c|c|c|c|c|}
\hline Designation & Membrane & $\begin{array}{l}\text { Anode } \\
\text { Loading }\end{array}$ & $\begin{array}{l}\text { Cathode } \\
\text { Loading }\end{array}$ & $\begin{array}{l}\text { Anode Gas diffusion } \\
\text { layers (GDL) Material }\end{array}$ & Cathode GDL Material \\
\hline QN1 & Nafion 117 & $\begin{array}{c}3 \mathrm{mg} / \mathrm{cm}^{2} \\
\mathrm{Pt} / \mathrm{Ru}\end{array}$ & $\begin{array}{c}0.5 \mathrm{mg} / \mathrm{cm}^{2} \\
\mathrm{PtB}\end{array}$ & $\begin{array}{l}\text { Carbon Paper } \\
\text { Freudenberg H2315, } \\
\text { unhydrophobised; } \\
\text { thickness } 230 \mu \mathrm{m}\end{array}$ & $\begin{array}{c}\text { Carbon Paper } \\
\text { Freudenberg H2315 with } \\
\text { Micro Porous Layer MPL } \\
\text { hydrophobised } \\
\text { thickness } 270 \mu \mathrm{m}\end{array}$ \\
\hline QN2 & Nafion 117 & $\begin{array}{c}3 \mathrm{mg} / \mathrm{cm}^{2} \\
\mathrm{Pt} / \mathrm{Ru}\end{array}$ & $\begin{array}{c}0.5 \mathrm{mg} / \mathrm{cm}^{2} \\
\mathrm{PtB}\end{array}$ & $\begin{array}{l}\text { Carbon Paper } \\
\text { Freudenberg H2315, } \\
\text { unhydrophobised; } \\
\text { thickness } 230 \mu \mathrm{m}\end{array}$ & $\begin{array}{c}\text { Carbon Paper } \\
\text { Sigracet } 10 \mathrm{BC} \\
5 \% \text { hydrophobised with MPL } \\
\text { thickness } 400 \mu \mathrm{m}\end{array}$ \\
\hline QN3 & Nafion 115 & $\begin{array}{c}3 \mathrm{mg} / \mathrm{cm}^{2} \\
\mathrm{Pt} / \mathrm{Ru}\end{array}$ & $\begin{array}{c}0.5 \mathrm{mg} / \mathrm{cm}^{2} \\
\mathrm{PtB}\end{array}$ & $\begin{array}{l}\text { Carbon Paper } \\
\text { Freudenberg H2315, } \\
\text { unhydrophobised; } \\
\text { thickness } 230 \mu \mathrm{m}\end{array}$ & $\begin{array}{c}\text { Carbon Paper } \\
\text { Freudenberg H2315 with MPL } \\
\text { hydrophobised } \\
\text { thickness } 270 \mu \mathrm{m}\end{array}$ \\
\hline QN4 & Nafion 115 & $\begin{array}{c}3 \mathrm{mg} / \mathrm{cm}^{2} \\
\mathrm{Pt} / \mathrm{Ru}\end{array}$ & $\begin{array}{c}0.5 \mathrm{mg} / \mathrm{cm}^{2} \\
\mathrm{PtB}\end{array}$ & $\begin{array}{l}\text { Carbon Paper } \\
\text { Freudenberg H2315, } \\
\text { unhydrophobised; } \\
\text { thickness } 230 \mu \mathrm{m}\end{array}$ & $\begin{array}{c}\text { Carbon Paper } \\
\text { Sigracet 10 BC } \\
5 \% \text { hydrophobised with MPL } \\
\text { thickness } 400 \mu \mathrm{m}\end{array}$ \\
\hline
\end{tabular}

According to the available manufacturer information, Sigracet gas diffusion layers are "graphitized" carbon fiber-based nonwovens, specifically designed to transport reactant gases into, and excess liquid product water out of, the electrocatalyst layers. This material has an open pore structure, good mechanical strength and high electrical conductivity. Freudenberg H2315 is a flexible and easy to use carbon paper. The MPL is used to build up the hydraulic pressure on the cathode side to promote the water back flow under this hydraulic pressure difference leading to a low net water flux trough the membrane [23].

All the experiments were performed at room temperature and the flowrates were maintained at $0.11 \mathrm{~mL} / \mathrm{min}$ for the methanol solution and $130 \mathrm{~mL} / \mathrm{min}$ for air. These values were found as the optimized flowrates for this micro fuel cell and presented in a previous work [24]. A similar optimal methanol flowrate was presented by Lu and Reddy [22] for a MicroDMFC with the same active area working at room temperature with a single serpentine flow field.

\section{Results and Discussion}

The polarization curves obtained by operating MEAs QN1 and QN2 with different methanol feed solutions are plotted in Figure 2.

The MEA QN1 was also tested for $2 \mathrm{M}$ methanol concentration because the performance obtained with $3 \mathrm{M}$ is slightly higher in the last part of polarization curve, generating higher power densities. However, the performance found for $2 \mathrm{M}$ was lower; therefore the optimum methanol concentration for this MEA is $3 \mathrm{M}$. For the MEA QN2 the same procedure was followed with a lower performance for a $5 \mathrm{M}$ methanol feed concentration. As is well established, the effect of the methanol concentration on the cell performance generally reflects two phenomena. On one side, an increase on the methanol concentration leads to a higher coverage of the electrocatalyst sites by methanolic species, but also increases the concentration gradient between the anode and cathode side with a consequent increment in the crossover through the Nafion membrane. On the other side, an increase in the limiting current density is obtained when higher methanol concentrations are used.

These two MEAs (based on Nafion 117), hot pressed from materials purchased from the same supplier, only differ with regards to the material used as the cathode gas diffusion layer. MEA QN2 
contains a Sigracet thicker cathode GDL, generating, as expected, a significant improvement in performance. This enhancement is evident in the plots of Figure 2 when comparing MEAS QN1 and QN2. The Sigracet GDL is more efficient at removing water drops. As mentioned before, this material is specifically designed to improve the transport of reactant gas into the catalytic layer and the removal of excess water. A significant increase in the limiting current density is also evident from the same plot when comparing the two MEAs working at the same level of methanol concentration. This is certainly due to the methanol crossover reduction imposed by the thicker cathode ( $270 \mu \mathrm{m}$ for the QN1 MEA and $400 \mu \mathrm{m}$ for QN2 MEA) ensuring a higher level of methanol concentration in the anode electrode.

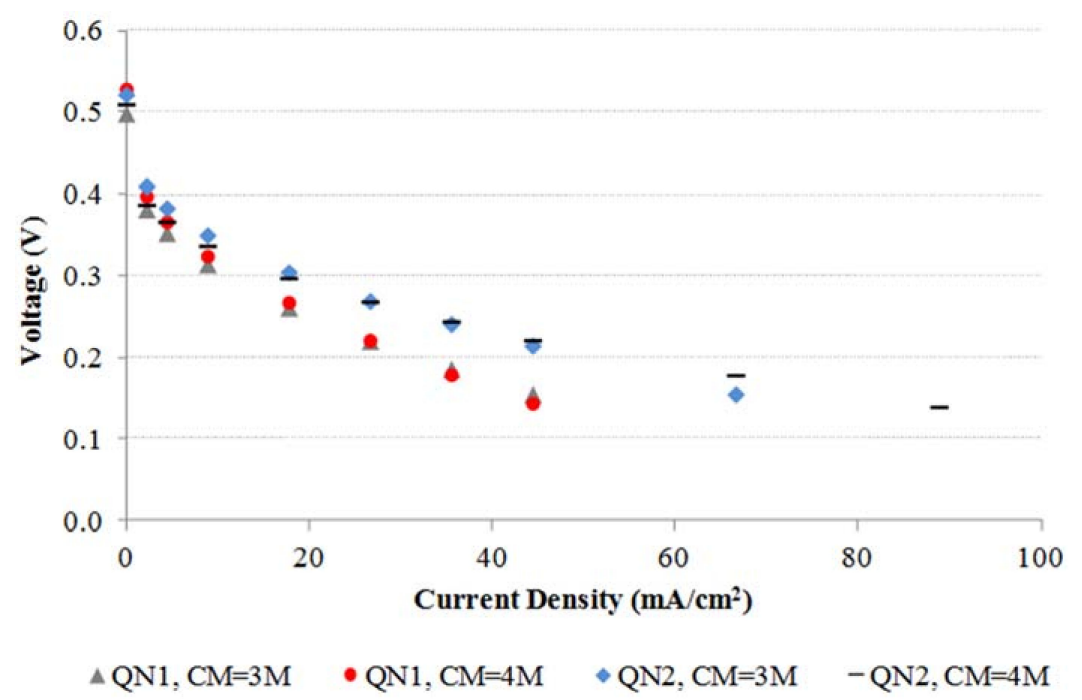

Figure 2. Voltage polarization curves comparison for MEAs QN1 and QN2 for different methanol feed concentrations (CM). Operating conditions: Temperature $25^{\circ} \mathrm{C}$, Pressure $1 \mathrm{~atm}$, Methanol/Air flow rates of $0.11 / 130 \mathrm{~mL} / \mathrm{min}$.

In Figure 3 the polarization curves for different methanol solutions for MEA's QN3 and QN4 are presented.

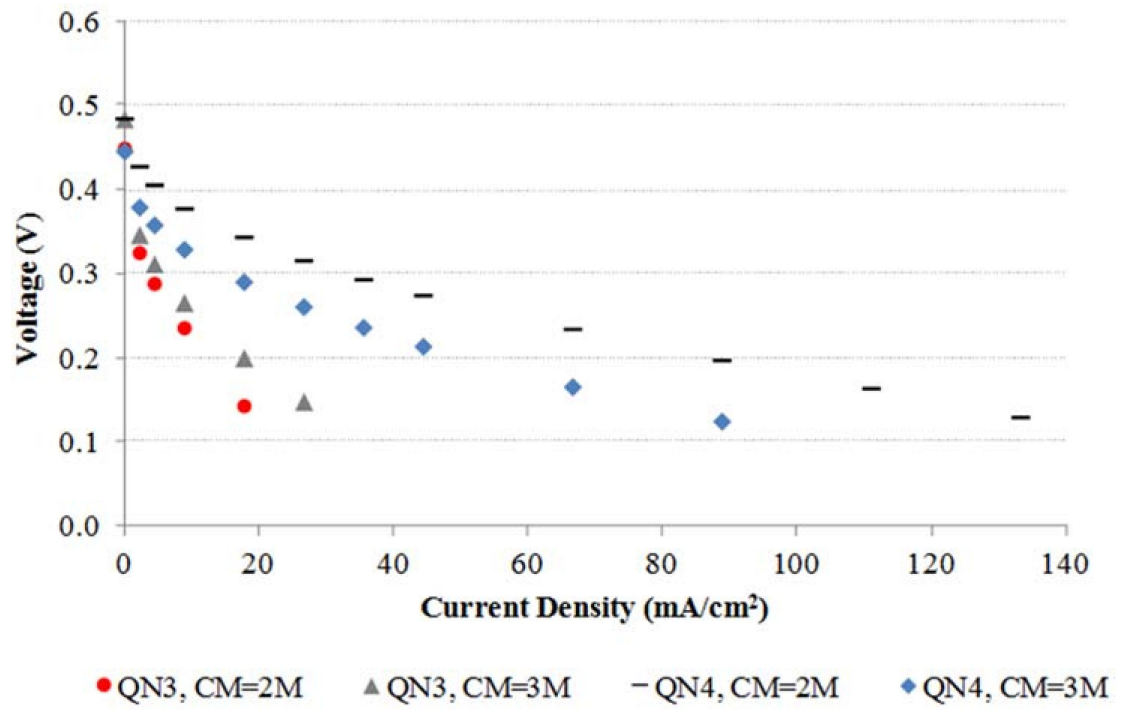

Figure 3. Voltage polarization curves comparison for MEAs QN3 and QN4 for different methanol feed concentrations (CM). Operating conditions: temperature, $25^{\circ} \mathrm{C}$; pressure, $1 \mathrm{~atm}$; methanol/air flow rates, $0.11 / 130 \mathrm{~mL} / \mathrm{min}$. 
The same trends were found when comparing in Figure 3 the cell performance of MEAs QN3 and QN4 both made up of Nafion 115 membranes and a different GDL structure (Table 1). Regarding the impact of methanol concentration, better results were obtained by feeding the cell with a $3 \mathrm{M}$ methanol solution for MEA QN3 and a $2 \mathrm{M}$ methanol concentration for MEA QN4. The MEA QN3 was also tested with a $4 \mathrm{M}$ methanol solution and the MEA QN4 with methanol solutions of $1 \mathrm{M}$ and $4 \mathrm{M}$. However the results obtained revealed lower cell performances in both cases. It is evident from the plots that the impact of the methanol concentration is, as expected, more pronounced for these thinner membranes, which potentiate higher levels of methanol crossover.

MEAs QN3 and QN4 (based on Nafion 115), differ with regards to the material used and the internal structure of the cathode GDL. Just as when MEAs QN1 and QN2 were compared in Figure 2, MEA QN4 (with the thicker Sigracet-based GDL) exhibits enhanced performances, providing evidence of an improved capacity for oxygen access and water removal. These better results are also due to a lower level of methanol crossover imposed by a significantly higher MEA thickness.

The cell polarization curves of MEAs QN1 and QN3 (same GDL structure and different membrane thickness) are compared in Figure 4.

The MEA based on Nafion 117 shows, as expected, better results due to a low methanol crossover generated with the higher membrane thickness. A substantially higher limiting current is evident in the QN3 plot for a similar methanol feed concentration due to a higher level of methanol concentration maintained through the electrode, arising from a significantly low level of reactant crossover.

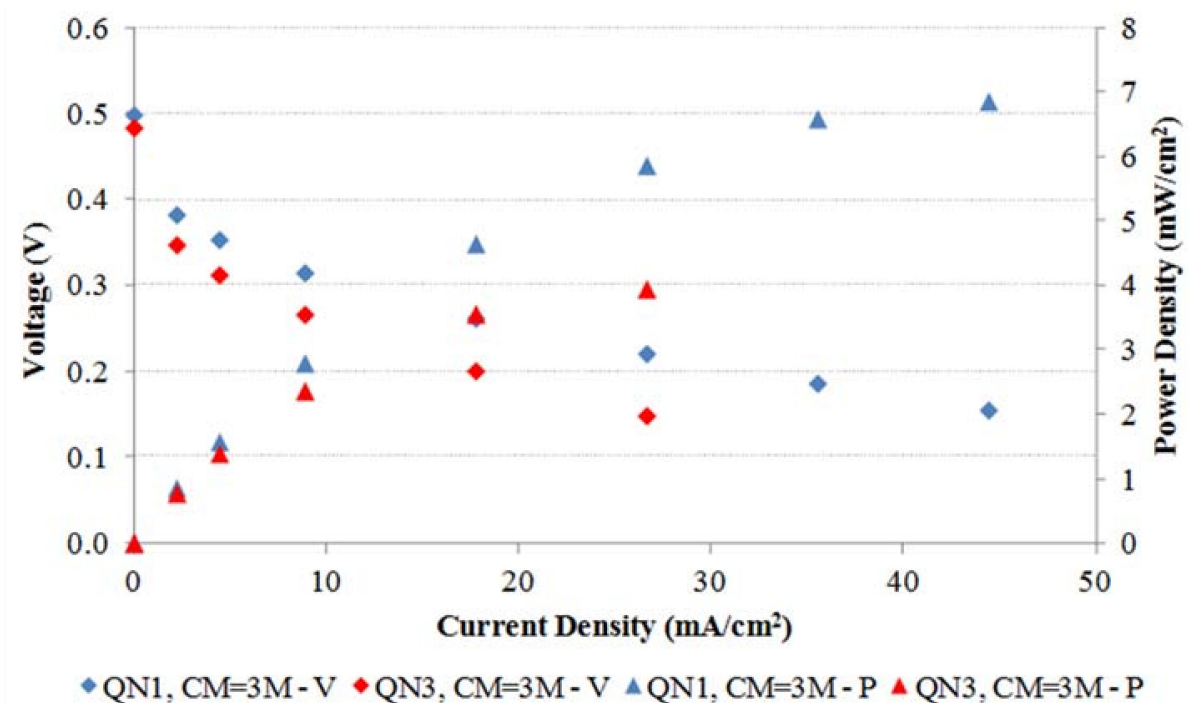

Figure 4. Voltage $(\mathrm{V})$ and power $(\mathrm{P})$ polarization curves comparison for MEAs QN1 and QN3 for the best methanol concentration (CM). Operating conditions: temperature, $25^{\circ} \mathrm{C}$; pressure, $1 \mathrm{~atm}$; methanol/air flow rates, $0.11 / 130 \mathrm{~mL} / \mathrm{min}$.

Figure 5 shows the better cell performances obtained with the MEAs QN2 and QN4.

These MEAs have the same GDL materials but have a modified Sigracet GDL structure and different Nafion thickness. Curiously the results are the opposite of those found in the previous figure. Much better results were obtained when using Nafion 115 membrane. A possible explanation for these results is the fact that the use of a thicker Sigracet material as cathode gas diffusion layer with MPL conjugated with a thinner membrane promotes a considerable water flux from the cathode to the anode, increasing the cell performance. The authors from [23] also concluded that the combined use of a thinner membrane and a thicker cathode gas diffusion media with MPL reduces the net water transport coefficient with improvements in fuel cell performance. Another plausible explanation is the improvement of protonic transfer through the thinner membrane. 


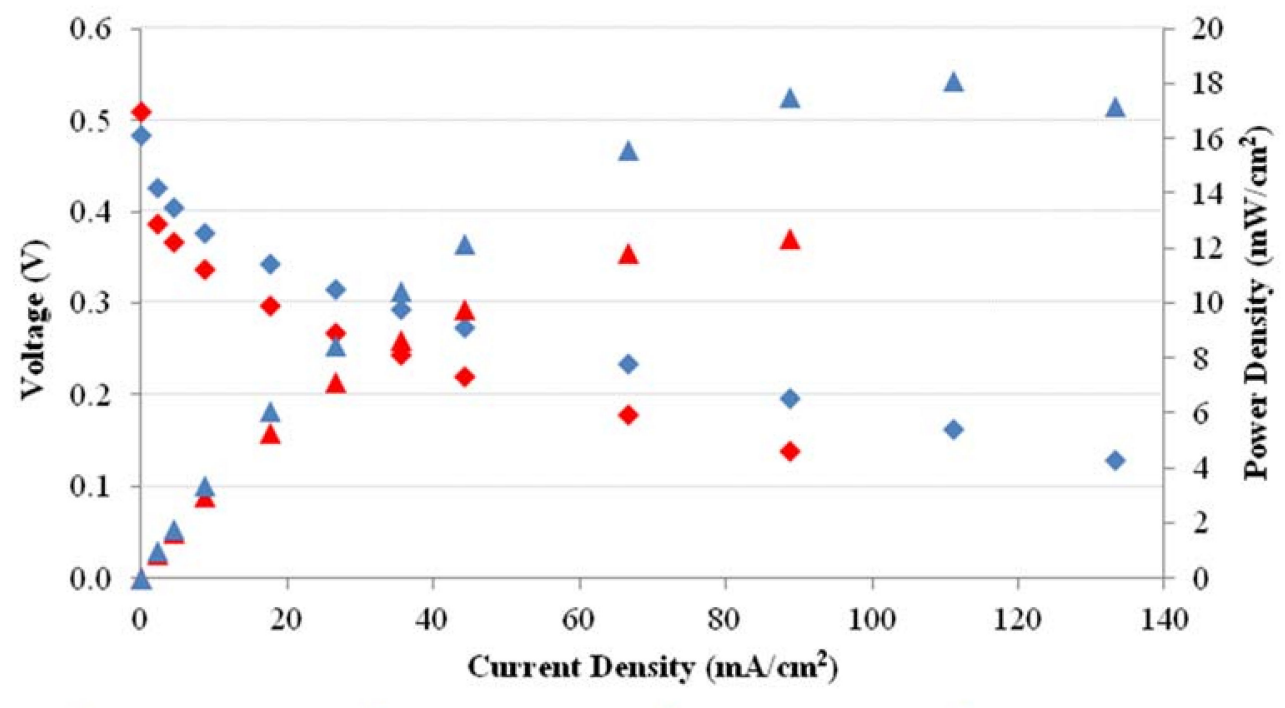

- $\mathrm{QN} 2, \mathrm{CM}=4 \mathrm{M}-\mathrm{V} \bullet \mathrm{QN} 4, \mathrm{CM}=2 \mathrm{M}-\mathrm{V} \triangle \mathrm{QN} 2, \mathrm{CM}=4 \mathrm{M}-\mathrm{P} \triangle \mathrm{QN} 4, \mathrm{CM}=2 \mathrm{M}-\mathrm{P}$

Figure 5. Voltage and power polarization curves comparison for MEAs QN2 and QN4 for the best methanol concentration (CM). Operating conditions: temperature, $25^{\circ} \mathrm{C}$; pressure, $1 \mathrm{~atm}$; methanol/air flow rates, $0.11 / 130 \mathrm{~mL} / \mathrm{min}$.

A summary of the maximum power output obtained with each MEA tested and the corresponding cost is presented in Table 2.

Table 2. Maximum power output corresponding to the better methanol concentration of each MEA tested and respective price.

\begin{tabular}{cccc}
\hline Designation & Methanol Concentration & Maximum Power Output $\left(\mathbf{m W} / \mathbf{c m}^{2}\right)$ & Price (Euros) \\
\hline QN1 & $3 \mathrm{M}$ & 6.8 & 15.7 \\
QN2 & $4 \mathrm{M}$ & 12.3 & 15.7 \\
QN3 & $3 \mathrm{M}$ & 3.9 & 15.3 \\
QN4 & $2 \mathrm{M}$ & 18.1 & 15.3 \\
\hline
\end{tabular}

The prices were calculated by multiplying the price per $\mathrm{cm}^{2}$ of each piece of electrode with catalyst loading and Nafion by the cell active area $\left(2.25 \mathrm{~cm}^{2}\right)$. These MEAs have a lower cost when compared to commercial MEAs already purchased from Quintech for previous studies (the cheapest one costing 29 euros for the same active area) with higher catalyst loadings $\left(4 \mathrm{mg} / \mathrm{cm}^{2} \mathrm{Pt} / \mathrm{Ru}\right.$ for anode and $4 \mathrm{mg} / \mathrm{cm}^{2} \mathrm{Pt}$ for cathode).

The comparison of the maximum performance obtained with MEA QN4-18.1 $\mathrm{mW} / \mathrm{cm}^{2}$ ( $3 \mathrm{mg} / \mathrm{cm}^{2} \mathrm{Pt}-\mathrm{Ru}$ at the anode and a cathode loading of $0.5 \mathrm{mg} / \mathrm{cm}^{2} \mathrm{PtB}$ ) with the ones reported in literature for active metallic micro fuel cells at room temperature using higher catalyst loading $[20,21]$ is very satisfactory. This value is only around 1.8 times less than the value reported by $\mathrm{Lu}$ and Wang [20] of $34 \mathrm{~mW} / \mathrm{cm}^{2}\left(22{ }^{\circ} \mathrm{C}\right.$ with $4.8 \mathrm{mg} / \mathrm{cm}^{2} \mathrm{Pt}-\mathrm{Ru}$ at anode and $1.8 \mathrm{mg} / \mathrm{cm}^{2} \mathrm{Pt}$ at the cathode) and 1.7 times lower than $32.87 \mathrm{~mW} / \mathrm{cm}^{2}$ reported by Zhang et al. [21] at $20{ }^{\circ} \mathrm{C}$ with anode loading of $4 \mathrm{mg} / \mathrm{cm}^{2} \mathrm{Pt}-\mathrm{Ru}$ and a cathode loading of $2 \mathrm{mg} / \mathrm{cm}^{2} \mathrm{PtB}$. As mentioned in the introduction section, Gogel et al. [15] found a performance reduction of about four times when using a cathode catalyst loading of $1 \mathrm{mg} / \mathrm{cm}^{2} \mathrm{Pt}$ instead of $2 \mathrm{mg} / \mathrm{cm}^{2} \mathrm{Pt}$.

It should be emphasized that in spite of a significant amount of published works reporting experimental tests with micro direct methanol fuel cells operating a temperatures above $40{ }^{\circ} \mathrm{C}$, there are a limited number of works reporting MicroDMFCs operating at room temperature, a condition of special interest bearing in mind portable applications. 


\section{Conclusions}

This paper presents a set of experiments with metallic MicroDMFCs operating at room temperature and made using commercially available materials. The fuel cell MEAs were produced using easily available materials, enabling the design of a micro fuel cell with enhanced performance in a short period of time.

Several MEAs with different characteristics were tested using different methanol concentrations. The optimal methanol concentration was determined for each MEA tested. The best choice is a MEA buildup of a Nafion 115 membrane and GDLs purchased from Quintech. The Sigracet-based thicker GDL used at the cathode joined with a thinner membrane generated a good cell performance with the use of a very low level of cathode catalyst loading. The price of this combination is around 15 euros for the MEA. The authors are not aware of works available in the literature reporting active MicroDMFCs operating MEAs with catalyst loadings as low as $0.5 \mathrm{mg} / \mathrm{cm}^{2}$.

There are few works relying on tests at room temperature for this type of fuel cells, therefore, the experimental data reported can be very useful for the scientific community.

Acknowledgments: The partial support of "Fundação para a Ciência e Tecnologia-Portugal" through project PTDC/EQU-FTT/112475/2009 and scholarship SFRH/BPD/109815/2015. POCI (FEDER) also supported this work via CEFT.

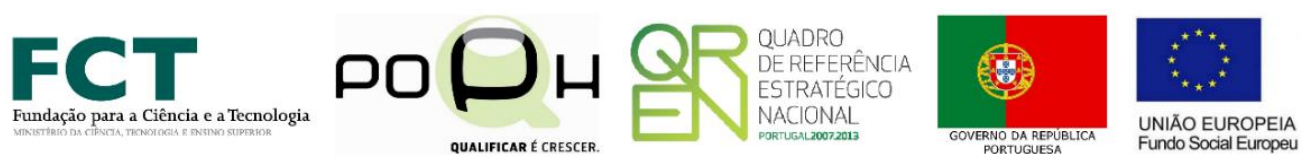

Author Contributions: D.S. Falcão and A.M.F.R. Pinto performed the experiments and wrote the manuscript. R.A. Silva and C.M. Rangel performed the MEAs hot pressing procedure and verified the manuscript text.

Conflicts of Interest: The authors declare no conflict of interest.

\section{References}

1. Wainright, J.S.; Savinell, R.F.; Liu, C.C.; Litt, M. Microfabricated fuel cells. Electrochim. Acta 2003, 48, 2869-2877. [CrossRef]

2. Kamarudin, S.K.; Daud, W.R.W.; Ho, S.L.; Hasran, U.A. Overview on the challenges and developments of micro-direct methanol fuel cells (DMFC). J. Power Sources 2007, 163, 743-754. [CrossRef]

3. Li, X.; Faghri, A. Review and advances of direct methanol fuel cells (DMFCs) part I: Design, fabrication, and testing with high concentration methanol solutions. J. Power Sources 2013, 226, 223-240. [CrossRef]

4. Sundarrajan, S.; Allakhverdiev, S.I.; Ramakrishna, S. Progress and perspectives in micro direct methanol fuel cell. Int. J. Hydrogen Energy 2012, 37, 8765-8786. [CrossRef]

5. Ong, B.C.; Kamarudin, S.K.; Basri, S. Direct liquid fuel cells: A review. Int. J. Hydrogen Energy 2017, 42, 10142-10157. [CrossRef]

6. Falcão, D.S.; Oliveira, V.B.; Rangel, C.M.; Pinto, A.M.F.R. Review on micro-direct methanol fuel cells. Renew. Sustain. Energy Rev. 2014, 34, 58-70. [CrossRef]

7. Nguyen, N.T.; Chan, S.H. Micromachined polymer electrolyte membrane and direct methanol fuel cells-A review. J. Micromech. Microeng. 2006, 16, R1-R12. [CrossRef]

8. Kamitani, A.; Morishita, S.; Kotaki, H.; Arscott, S. Miniaturized microdmfc using silicon microsystems techniques: Performances at low fuel flow rates. J. Micromech. Microeng. 2008, 18, 125019. [CrossRef]

9. Meng, D.D.; Kim, C.J. An active micro-direct methanol fuel cell with self-circulation of fuel and built-in removal of co2 bubbles. J. Power Sources 2009, 194, 445-450. [CrossRef]

10. Zhang, Y.; He, H.; Yuan, Z.; Wang, S.; Liu, X. Effect of design and operating parameters on dynamic response of a micro direct methanol fuel cell. Int. J. Hydrogen Energy 2011, 36, 2230-2236. [CrossRef]

11. Zhang, Q.; Wang, X.; Zhu, Y.; Zhou, Y.; Qiu, X.; Liu, L. Optimized temperature control system integrated into a micro direct methanol fuel cell for extreme environments. J. Power Sources 2009, 192, 494-501. [CrossRef] 
12. Zhang, Q.; Wang, X.; Zhong, L.; Zhou, Y.; Qiu, X.; Liu, L. Design, optimization and microfabrication of a micro-direct methanol fuel cell with microblocks in anode structure. Sens. Actuators A 2009, 154, 247-254. [CrossRef]

13. Zhang, Y.F.; Wang, L.W.; Yuan, Z.Y.; Wang, S.B.; Li, J.M.; Liu, X.W. Silicon-based micro direct methanol fuel cell with an n-inputs-n-outputs anode flow pattern. Chin. Sci. Bull. 2011, 56, 826-829. [CrossRef]

14. Hashim, N.; Kamarudin, S.K.; Daud, W.R.W. Design, fabrication and testing of a pmma-based passive single-cell and a multi-cell stack micro-dmfc. Int. J. Hydrogen Energy 2009, 34, 8263-8269. [CrossRef]

15. Gogel, V.; Frey, T.; Yongsheng, Z.; Friedrich, K.A.; Jörissen, L.; Garche, J. Performance and methanol permeation of direct methanol fuel cells: Dependence on operating conditions and on electrode structure. J. Power Sources 2004, 127, 172-180. [CrossRef]

16. Ghayor, R.; Shakeri, M.; Sedighi, K.; Farhadi, M. Experimental and numerical investigation on passive and active $\mu$ DMFC. Int. J. Hydrogen Energy 2010, 35, 9329-9337. [CrossRef]

17. Zhang, Y.; Zhang, P.; He, H.; Zhang, B.; Yuan, Z.; Liu, X.; Cui, H. A self-breathing metallic micro-direct methanol fuel cell with the improved cathode current collector. Int. J. Hydrogen Energy 2011, 36, 857-868. [CrossRef]

18. Han, W.; Cheung, C.T.; Poon, H.Y.; Yeung, K.L. A new structured composite membrane for fuel cell applications. Catal. Today 2012, 193, 194-199. [CrossRef]

19. Liu, X.; Zhang, B.; Zhang, Y.; He, H.; Li, J.; Wang, S.; Yuan, Z.; Deng, H. Development and characterization of a novel air-breathing micro direct methanol fuel cell stack for portable applications. J. Micromech. Microeng. 2010, 20, 104008. [CrossRef]

20. Lu, G.Q.; Wang, C.Y. Development of micro direct methanol fuel cells for high power applications. J. Power Sources 2005, 144, 141-145. [CrossRef]

21. Zhang, Y.; He, H.; Fan, Q.; Zhang, B.; Liu, X.; Tian, L.; Tan, K. Effect of cathode gas flow patterns on performance of micro direct methanol fuel cell. In Proceedings of the 2010 Academic Symposium on Optoelectronics and Microelectronics Technology and 10th Chinese-Russian Symposium on Laser Physics and Laser Technology, Harbin, China, 28 July-1 August 2010; pp. 326-329.

22. Lu, Y.; Reddy, R.G. Effect of flow fields on the performance of micro-direct methanol fuel cells. Int. J. Hydrogen Energy 2011, 36, 822-829. [CrossRef]

23. Liu, F.Q.; Lu, G.Q.; Wang, C.Y. Low crossover of methanol and water through thin membranes in direct methanol fuel cells. J. Electrochem. Soc. 2006, 153, A543-A553. [CrossRef]

24. Falcão, D.S.; Oliveira, V.B.; Rangel, C.M.; Pinto, A.M.F.R. Experimental and modeling studies of a micro direct methanol fuel cell. Renew. Energy 2015, 74, 464-470. [CrossRef] 